\title{
Rosewood Oil
}

National Cancer Institute

\section{Source}

National Cancer Institute. Rosewood Oil. NCI Thesaurus. Code C72203.

The essential oil extracted from the wood of Aniba rosaeodora. Rosewood oil is used for aromatherapy and an ing redient in skincare products. 